Abstracta Iranica Abstracta Iranica

Revue bibliographique pour le domaine irano-aryen

Volume 23 | 2002

Comptes rendus des publications de 2000

Le Livre des théophanies d'Ibn 'Arabî, introduction philosophique, commentaire et traduction annotée du Kitâb al-tajalliyât. Paris, Cerf, 2000, 392 p.

Pierre Lory

(2) OpenEdition

Journals

Édition électronique

URL : http://journals.openedition.org/abstractairanica/35601

DOI : 10.4000/abstractairanica.35601

ISSN : 1961-960X

Éditeur :

CNRS (UMR 7528 Mondes iraniens et indiens), Éditions de l'IFRI

Édition imprimée

Date de publication : 15 mai 2002

ISSN : 0240-8910

Référence électronique

Pierre Lory, "Le Livre des théophanies d'Ibn 'Arabî, introduction philosophique, commentaire et traduction annotée du Kitâb al-tajalliyât. Paris, Cerf, 2000, 392 p. », Abstracta Iranica [En ligne], Volume 23 | 2002, document 225, mis en ligne le 08 février 2010, consulté le 25 septembre 2020. URL : http:// journals.openedition.org/abstractairanica/35601 ; DOI : https://doi.org/10.4000/abstractairanica. 35601

Ce document a été généré automatiquement le 25 septembre 2020.

Tous droits réservés 


\section{Le Livre des théophanies d'Ibn 'Arabî, introduction philosophique, commentaire et traduction annotée du Kitâb al-tajalliyât. Paris, Cerf, 2000, 392 p.}

\section{Pierre Lory}

Nous avons affaire ici à la traduction française d'un important ouvrage d'Ibn 'Arabī, dont Oțān Yahyā avait fourni une édition critique (rééd. Téhéran 1988 sous le titre al-Tajalliyāt al-ilāhiyya). S.R. encadre sa traduction d'une imposante introduction, l'accompagne d'un appareil considérable de notes infrapaginales et la fait suivre d'une présentation systématique de la plupart des «théophanies » du texte. L'ensemble de ces commentaires contient à la fois des références bibliographiques diverses, des précisions doctrinales et des opinions plus personnelles. Le Livre des théophanies méritait en tout état de cause d'être connu du public français : il contient notamment de nombreux passages vibrants voire lyriques (chap. 81-84), ainsi que de fameuses rencontres dans l'intermonde avec des soufis des siècles précédents comme Junayd, Tustarī ou Ḥallāj (chap. 55 et suivants). D'autres chapitres sont nettement plus obscurs, ésotériques, prouvant que le discours soufi n'est par moment accessible qu'à des véritables initiés. 
INDEX

Thèmes : 8. Soufisme

\section{AUTEURS}

PIERRE LORY

EPHE - Paris 